This article was downloaded by: [Rönnbäck, Anna Öhrwall]

On: 23 July 2009

Access details: Access Details: [subscription number 913325648]

Publisher Taylor \& Francis

Informa Ltd Registered in England and Wales Registered Number: 1072954 Registered office: Mortimer House, 37-41 Mortimer Street, London W1T 3JH, UK

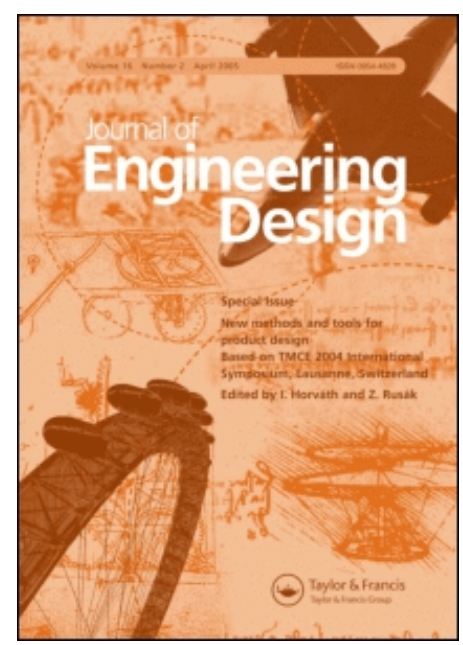

Journal of Engineering Design

Publication details, including instructions for authors and subscription information:

http://www.informaworld.com/smpp/title content=t713429619

\title{
Development of product-service systems: challenges and opportunities for the
} manufacturing firm

Ola Isaksson ab; Tobias C. Larsson b; Anna Öhrwall Rönnbäck c

a Volvo Aero Corporation, Trollhättan, Sweden ${ }^{b}$ Division of Functional Product Development, Luleå University of Technology, Luleå, Sweden ${ }^{\circ}$ Department of Management and Engineering, Linköping University,

Linköping, Sweden

Online Publication Date: 01 August 2009

To cite this Article Isaksson, Ola, Larsson, Tobias C. and Rönnbäck, Anna Öhrwall(2009)'Development of product-service systems: challenges and opportunities for the manufacturing firm',Journal of Engineering Design,20:4,329 — 348

To link to this Article: DOI: $10.1080 / 09544820903152663$

URL: http://dx.doi.org/10.1080/09544820903152663

\section{PLEASE SCROLL DOWN FOR ARTICLE}

Full terms and conditions of use: http://www.informaworld.com/terms-and-conditions-of-access.pdf

This article may be used for research, teaching and private study purposes. Any substantial or systematic reproduction, re-distribution, re-selling, loan or sub-licensing, systematic supply or distribution in any form to anyone is expressly forbidden.

The publisher does not give any warranty express or implied or make any representation that the contents will be complete or accurate or up to date. The accuracy of any instructions, formulae and drug doses should be independently verified with primary sources. The publisher shall not be liable for any loss, actions, claims, proceedings, demand or costs or damages whatsoever or howsoever caused arising directly or indirectly in connection with or arising out of the use of this material. 


\title{
Development of product-service systems: challenges and opportunities for the manufacturing firm
}

\author{
Ola Isaksson $^{\mathrm{a}, \mathrm{b}}$, Tobias C. Larsson ${ }^{\mathrm{b}}$ and Anna Öhrwall Rönnbäck ${ }^{\mathrm{c} *}$ \\ ${ }^{a}$ Volvo Aero Corporation, Trollhättan, Sweden; ${ }^{b}$ Division of Functional Product Development, Luleå \\ University of Technology, Luleå, Sweden; ${ }^{c}$ Department of Management and Engineering, Linköping \\ University, Linköping, Sweden
}

(Received 27 April 2009; final version received 1 June 2009)

\begin{abstract}
Product-Service Systems (PSS) raise interesting opportunities for the manufacturing firm as the function is provided to meet customer needs rather than the physical hardware itself. PSS offerings based on the manufacturer's knowledge about the product and the technology can increase its status as problem-solver and solution-provider, reduce life cycle cost and produce high revenue. However, PSS including, e.g. hardware, services, software and electronics are efficient and competitive only if developed for the specific purpose with features such as easy to maintain, upgradeable, with built-in sensors for collecting in-use and service data, and easy to use. This changes the requirements on the manufacturing firm's development process. Looking back historically, the last century gives an interesting changing landscape of the rationale for the product-development methods used in manufacturing firms. This article, based on the previous research in the product- and service-development fields, and on empirical results from studies at several manufacturing firms, looks into how the engineering work is affected by PSS and how it can be enhanced for PSS, especially in terms of required competencies and other capabilities. It results in recommendations for a new, functional product-development process.
\end{abstract}

Keywords: product service systems; functional product development; integrated solutions; engineering methods

\section{Introduction and background}

\subsection{Drivers for product-service systems and consequences for the product-development process}

In search for an increased customer value combined with optimal resource utilisation, manufacturing firms have the last decade rather oriented their offerings towards function instead of product (Vandermerwe 2000, Senge and Carstedt 2001, Alonso-Rasgado et al. 2004, Brännström 2004, Kowalkowski 2008). IKEA, as an example, offers 'to create a home' instead of selling furniture. Rolls Royce offers 'Total Care' and 'power by the hour' rather than selling jet engines and spare parts. Flygt of ITT Industries offers 'cleaning solutions' instead of selling pumps.

*Corresponding author. Email: anna.ohrwall.ronnback@liu.se

ISSN 0954-4828 print/ISSN 1466-1837 online

(C) 2009 Taylor \& Francis

DOI: $10.1080 / 09544820903152663$

http://www.informaworld.com 
In another case, Toyota Material Handling Sweden suggests Do not buy a forklift truck to their customers; instead, the customer is offered the warehouse transportation function, and maintenance and finance are taken care of by the truck manufacturer. Such offerings include services, hardware and software, and are referred to as 'functional sales', 'concepts', 'system solutions', 'soft products', 'integrated solutions', 'industrial services', 'integrated product and service offerings' or 'product-service systems' (PSS).

The main business arguments for both customers and providers are increased customer value, a long-term improved return on investment, and a more stable cashflow management. The business model is also strongly supported for its built-in environmental-friendly aspects and possible spare part and waste reductions with lower cost as a consequence. If the manufacturer provides and guarantees function instead of product, it lies in the interest of the manufacturer that the equipment is used as efficiently as possible. If the ownership stays with the manufacturer, maintenance and repair implies cost for the manufacturing firm, instead of representing a possibly lucrative after-sales business. (Alonso-Rasgado et al. 2004, Brännström 2004) With functional products, the interaction between the provider and the customer (professional or private consumer) becomes more sophisticated. The consequence for the customer might be that a smaller organisation now is needed for support, since this instead is provided by the supplier. Consequences for the provider of functions may be increased life cycle responsibility, new legislation for responsibility for re-cycling, ownership with rental agreements instead of sold hardware units, and increased involvement in the customer's business processes.

The focus on function and integration of services obviously affects the manufacturer's development process, i.e. how development work is organised and which tools and methods are used. Alonso-Rasgado et al. (2004) focus on the service-design process in a PSS context. In this paper, we argue that the service and hardware should be developed in one coordinated development process. For successful PSS solutions, new aspects probably need to be taken into account at the early phases of the development process and that the physical artefact needs to be tailored to the new conditions of use due to PSS provision. The driver behind PSS is triple gain: for the customer (utilising the function provided), the provider (manufacturing, maintaining and remanufacturing the equipment), and the environment and society at large, since less waste is produced (Östlin et al. 2008). Manufacturing firms that understand how this shift in business conditions relates to their traditional and future products are likely to discover many opportunities for their products, processes and business. With the shift, the manufacturing firm can provide services during the complete life cycle of the physical product, such as operations on the installed base (Oliva and Kallenberg 2003).

The bottom line is that the shift in the way the manufacturing firm does business has an impact on the way products are developed and realised. Traditionally, the manufacturing firm has focused on the physical artefacts, while services, such as installation, maintenance, training or finance, have been seen as add-on to the already developed and produced artefact. This is also reflected in the PSS terminology used today. In fact, the product construct is changing as the term 'product' in practice often refers to 'what is sold', as indicates the ISO standard notion of a product:

A product is an output that results from a process. Products can be tangible or intangible, a thing or an idea, hardware or software, information or knowledge, a process or procedure, a service or function, or a concept or creation. (ISO 9001: 2000)

The term product-service system (PSS) leads to some confusion since 'product' in this case already might contain the service notion, hardware, software and services being parts that build up the product according to the ISO definition. To clarify, we use the following terminology (see Figure 1), i.e. a customer has a need of some specific functionality, which is provided as a PSS solution by the provider, which in this case is a manufacturing firm. The PSS solution is similar to the ISO definition of the term product, i.e. can include both physical parts and services, or at the extreme (depending on customer demand of function) only one of these. 


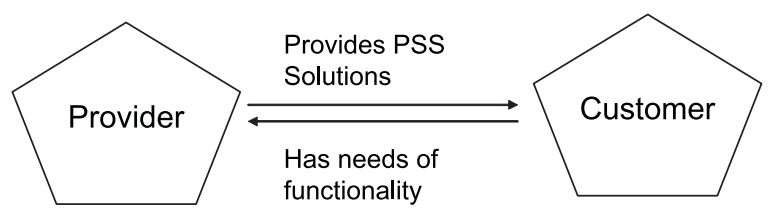

Figure 1. Provider of PSS solution and customer in need of functionality.

A changed view on the development process is not a new phenomenon. Since the industrial era started some hundred years ago, the competitive wheel has always affected the way manufacturing firms develop, produce and provide products and services to customers. Figure 2 illustrates how the development function in a firm has evolved over the last decades. Shifts in trends are most often influenced by the related areas and disciplines; societal challenges and customer behaviour to mention some. The large study of the automotive industry during the 1980s and 1990s (International Motor Vehicle Programme, IMVP) revealed for example imperfections in the American and European way of not only producing but also developing cars, compared with the Japanese, often referred to as The Toyota Way (Womack et al. 1990). The throw-over-the-wall attitude between departments involved in the development work was replaced by sashimi, i.e. to plan development activities in parallel instead of in a row, also referred to as concurrent engineering or rugby, to do many activities simultaneously to gain time and share knowledge between disciplines (Dussauge et al. 1987, Wheelwright and Clark 1992). Lately, factors such as globalisation, individualism, information access and teamware, and modularisation, as well as collaboration with suppliers, partners, and lead users, have impacted product development trends (von Hippel 1988, 2005, Smith and Reinertsen 1991, McAloone 2008).

The point being made is that the manufacturing firm's development activities remain, but the understanding of drivers of product functionality changes, and so does the way products are

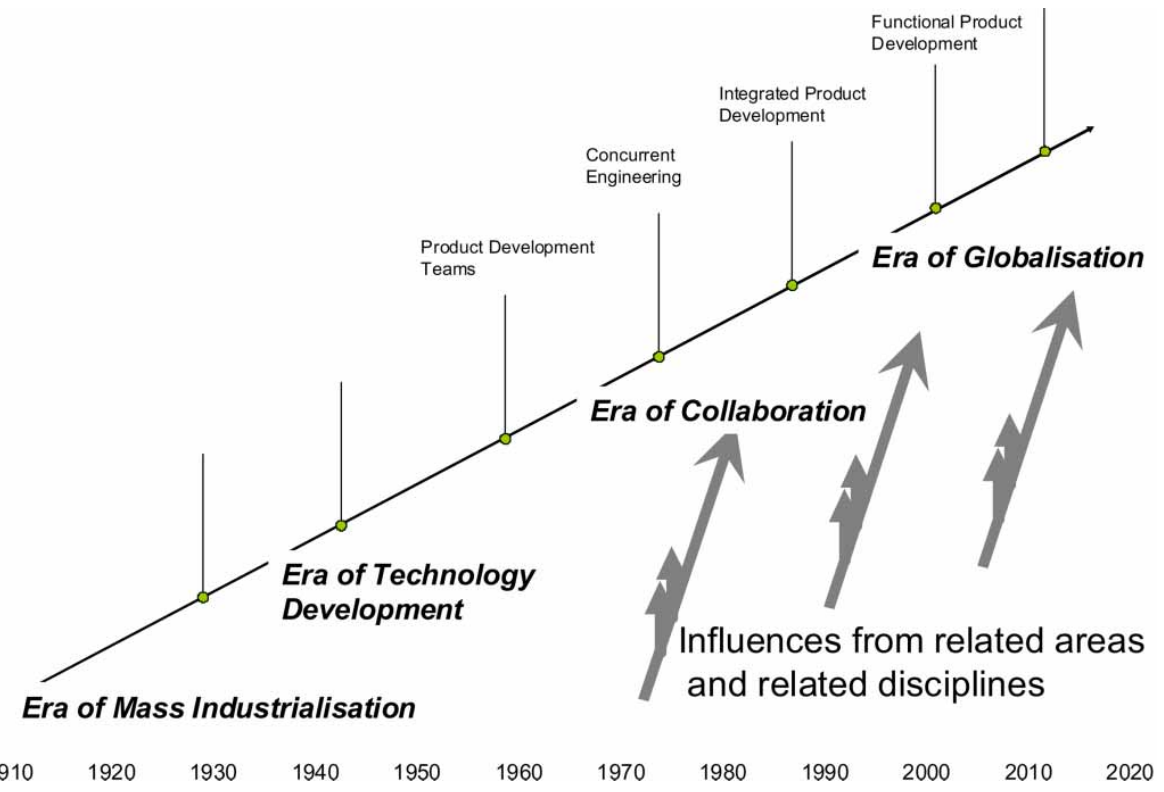

Figure 2. Evolution of product development: from the 'era of industrialisation' to the 'era of globalisation'. 
developed. The prevailing trend today of offering functionality leads us to refer to the development process as 'functional product development' (FPD).

\subsection{Objective}

Extensive research has addressed service productivity for manufacturing firms providing PSS (Kowalkowski 2008, Vargo and Lusch 2008). However, the consequences of PSS on the product development process also need to be elucidated. Moreover, Alonso-Rasgado et al. (2004) concluded in their review of service development literature for the purpose of designing functional products that general service design principles [...] are inappropriate for functional products (p. 537).

The objective of this paper is therefore to further examine the consequences that a manufacturing firm's movement towards PSS has on the product development process. More specifically, the two main questions addressed are as follows:

- How is the engineering work affected, and how can it be enhanced, in order to account for business models for PSS (i.e. combinations of hardware, software, and services)?

- What competences are required in development work, in particular in the solution design team, for the manufacturing firm to become more capable of providing successful PSS?

\subsection{Method}

This research is based on industrial case studies in manufacturing firms (Eisenhardt 1989, Yin 1994).

The empirical basis for this work is case studies of business opportunities and business model transitions towards larger service content for 12 companies and their different solutions (offerings), where tools and methods for PSS design (the engineer's working environment) and examples of engineering tools available and implementation have been studied.

Data were collected during 2003-2008 through semi-structured interviews with company managers and product development engineers, workshops, company visits, and by reading general company information on the firms' web sites as well as brochures and the like.

\section{Development of products and services}

\subsection{Generals on product development}

This chapter will focus on the existing baseline in product-development research with special aspects on integrated product development (IPD) and service management and service development and customer needs, as a background to the next chapter that focuses PSS development, where the below-mentioned components play a vital part (as suggested e.g. by Alonso-Rasgado et al. 2004).

By tradition, the product-development literature focuses on the development of physical goods, i.e. things (Pugh 1991, Roozenburg and Eekels 1995, Ulrich and Eppinger 2007). The literature focuses on engineering areas, such as mechanical, electrical, software or construction areas. Computer software, control systems and microprocessors have become an integrated part of the physical artefact (Ullman 2003). On a general level, Ulrich and Eppinger (2007) define a product as ... something sold by an enterprise to its customers, but narrow the focus to stand for something that is ... engineered, discrete, and physical (p. 2). Other literature argue that it is ... an acknowledged fact that all products are manufactured (Pugh 1991, p. 148). 
A product-development process is viewed as a transformation (Krishnan and Ulrich 2001) or a translation (Baxter 1995) of a market opportunity into a physical artefact available for sale. The structure for a development process is described as ... the sequence of steps or activities that an enterprise employs to conceive, design and commercialize a product (Ulrich and Eppinger 2007, p. 14).

Figure 3 depicts the sequence of steps of a product-development process where important manufacturing constraints and considerations are outlined as feedback arrows. Product-development processes are sometimes described without the manufacture, sales, and support phases. This is the traditional view on product development of artefacts.

Consequently, models that visualise the development process outline a ... set of activities beginning with the perception of a market opportunity and ending in the production, sale and delivery of a product (Ulrich and Eppinger 2007, p. 2). Being customer-oriented and listening closely to your customers to meet or even exceed their needs is a common statement that has been prevalent in manufacturing firms for the past decade. To realise this, however, is not as easy as it seems. Customer-orientation suggests an 'outside in' perspective of the manufacturing firm (Grönroos 2000). Further, another common characteristic is the given emphasis to an iterative process. Several models of such processes are presented in the product-development literature. A common characteristic for these models is that an initial input to the processes comes from market needs or specific customer problems, etc., i.e. customer issues gathered in the market-research activities (Pugh 1991, Pahl and Beitz 1996, Ulrich and Eppinger 2007).

Besides a market opportunity, the product-development process can be triggered by the development of a new technology. Regardless of what initiates the process, some kind of market research or customer analysis is suggested as the starting point. (Pugh 1991, Ulrich and Eppinger 2007).

Based on how activities were performed and on information flows, the product-development process was previously known as an over-the-wall process, or a relay race (Ullman 2003, Dussauge et al. 1987). For example, people at sales and marketing departments identify and decide on a market opportunity needs or a problem. They interpret and put together their information into a requirement specification, which is passed over to the design department. At the design department, interpretation of the requirement specification into a design specification is made; this information is then passed on to the production units who interpret the information and build what they think the design engineers want. It is suggested that a product-development process needs to be broken down to be logical and comprehensible. Firstly, it is broken down into phases and secondly, into distinct steps, but each step has its own working methods. The output from each step is input in the next and there are iterative loops from each step to monitor and control, for example changed circumstances (Pahl and Beitz 1996, Ullman 2003).

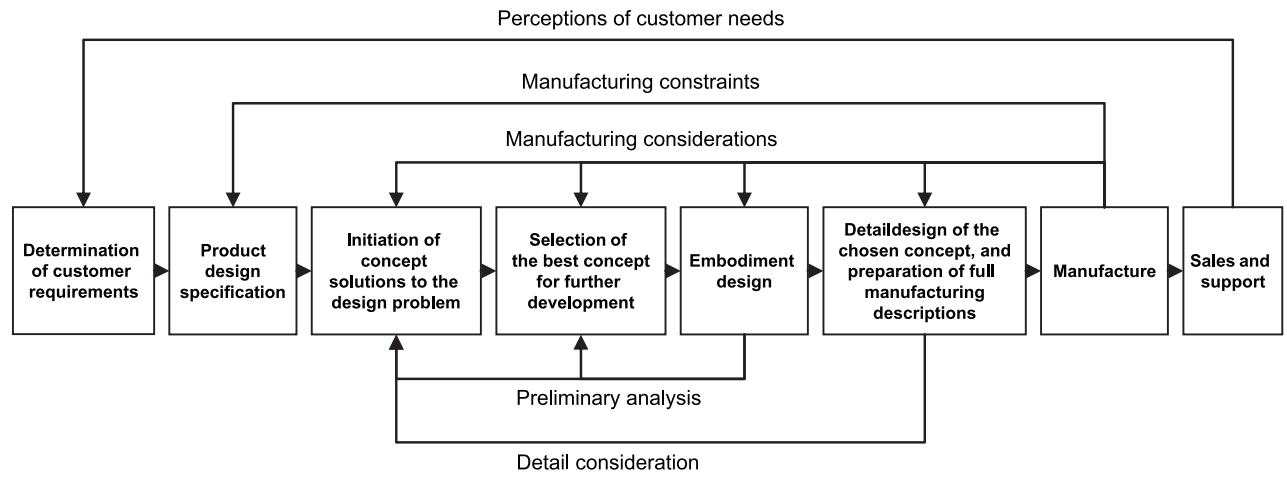

Figure 3. A product-development process (interpreted from Wright 1998). 


\subsection{Organisation of product development: IPD}

In early engineering product-development literature, the main task of development engineers is to use their knowledge to solve technical problems (Pahl and Beitz 1996). Today, an increasing complexity in modern technology makes it rarely possible for individuals to design and develop a major new product (Ullman 2003). A design team is required, thereby also introducing problems of organisation and communication. Product development becomes IPD by involving the whole business. On an overarching level, IPD brings together the organisational functions of marketing, design and production (Andreasen and Hein 1987). Concurrent engineering, design for manufacturing, early manufacturing involvement, time-based competition, visual planning, lean philosophies and linked Japanese practices could be seen as various manifestations of IPD (Womack et al. 1990, Wheelwright and Clark 1992, Gerwin and Barrowman 2002).

An overall view of an IPD process highlights that the working tasks should be carried out in a concurrent or parallel iterative process (Andreasen and Hein 1987, Hartley 1992, Roozenburg and Eekels 1995, Prasad 1996), see Figure 4. Hence, IPD supports overlap and integration between activities, and good communication is insisted (Gerwin and Barrowman 2002).

Gerwin and Barrowman (2002) view IPD as the paradigm for new product development and as a managerial approach for improving the product-development performance. The management of development processes can be seen as a balancing effort toward four key objectives: (1) development speed, as reduced development time is seen as a benefit from an IPD process, (2) product cost, (3) product performance and (4) development program expense. Good trade-offs between these four objectives are considered as the art of managing product development (Smith and Reinertsen 1991).

The design teams are recommended to be multifunctional (Prasad 1996) and covering a sufficient diversity of knowledge (Ulrich and Eppinger 2007). Roozenburg and Eekels (1995) describe the goal of the technical development process as producing a number of products according to a particular design, and the goal for the commercial development processes as profit. The product as such ...forms the link between the technical and commercial development process (p. 21). Hence, interaction takes place between the functional units; this raises questions of coordination.

Working in design teams adds a social aspect to the design process. Each team member interprets the problem differently, has different suggestions for solving it and has different knowledge. However, working together jointly ... ensures that the product does everything it must to be a commercial success (Baxter 1995, p. 18). As a whole, the view on design is affected by the emphasis on cross-functional design teams. Design could be viewed as ... the organization and management of people and the information they develop in the evolution of a product (Ullman 2003, p. 8).

Characteristics for IPD research are a focus on integrated tools, incremental development, organisational issues to reduce task specialisation and cross-functional teams, according to Gerwin and Barrowman (2002), who identify three branches of IPD studies:

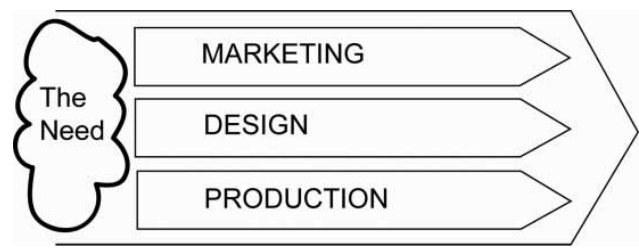

Figure 4. An overall view of IPD process, from Andreasen and Hein (1987). 
- IPD as organisational design, which focuses on structural adaptations to environmental and technological factors.

- IPD as an information-processing approach, which focuses on transformation of data on market opportunities and technological possibilities into a product-design solution.

- IPD as an application of total quality management (TQM) principles.

TQM includes several factors that are seen as determinants of success or failure, for example how well a product ... responds to customer needs, the manufacturability of the design, and the robustness of its design quality (Clausing 1994, p. 94).

Krishnan and Ulrich (2001) outlines product-development research, and suggests four common perspectives where (1) marketing, (2) organisation, (3) engineering design and (4) operations management research are the basis. Each perspective holds a different view on products, which is helpful in understanding the underlying interpretation of how literature from different research areas contributes to models and methods for product development. A special case is when more than one firm needs to be involved in the IPD activities, such as when a small firm does not have all required resources inhouse (Biemans 1995), or when the development projects are too large and complex, such as in the aircraft industry (Hamel et al. 1989). Collaborative product development involves strategic procurement and supplier relationships, and communication over company borders (See e.g. Bruce et al. 1995, Lambert and Cooper 2000, Öhrwall Rönnbäck 2002).

\subsection{Service management and service development}

Service-management literature focuses on the management of intangible aspects, e.g. customer relationships, networks, customer-perceived value, or customer's perception of quality. The key lies in the 'moment of truth', as suggested in Normann (1983), when the service provider effectuates the service for the customer. Normann and Ramírez (1993) suggest value constellation rather than a value chain, indicating that value is created at the user side when the provider's offering is consumed, i.e. instead of output from a supply chain it serve as input to the customer's valuecreation process. Although physical goods are tangible, services are intangible. Physical goods are things and services are activities (Grönroos 2000). The logic of producing services is different from producing hardware (Edvardsson et al. 2000). Physical artefacts can be delivered, i.e. being moved from one place to another, but services cannot, since they are produced and used just as needed and at a time and place of the customer's choosing (Edvardsson et al. 2000, Grönroos 2000). Services are co-produced in relationships, networks and through interaction (Gummesson 2002). Concerning the notion of product, service-development researchers use terminology in line with the ISO definition previously mentioned:

A service is viewed as part of the wider concept product. A product can be a commodity, a service, computer software or - more common - a combination of these. A product is the result of a production process. (Edvardsson and Modell 1996, p. 19)

Even though a service is not a thing, a customised solution where the machine or almost any physical artefact is used, can be turned into a service:

A machine is still a physical good, of course, but the way of treating the customer with an appropriately designed machine is a service. (Grönroos 2000, p. 45)

The view on hardware from a service-management perspective reduces hardware to distribution mechanisms for service provision. As the focus has shifted from tangibles to intangibles, skills, information, knowledge, interactivity and connectivity in relationships are now in focus (Vargo and Lusch 2004). 
Services can be seen as occurring both within the company and between the company and its customers (Normann 2001). Services can be made visible or remain invisible. Examples of invisible services are how a company manages and handles invoicing, quality problems, complaints, offers documentation, handles queries and offers customers training on how to use machines (Grönroos 2000). To make the invisible services visible means that the provider can achieve payment for them. Hence, from a service point of view, the physical artefact is not the only price carrier (Fransson 2004). But, in service literature, financial outcomes . . . are not something to be maximized but something to learn from as firms try to serve customers better and improve their performance (Vargo and Lusch 2004, p. 6).

The service concept, service process and service system are vital components to the outcome of the service development. The service company must develop and offer a service concept which is appropriate to the customer's needs and which contains attractive added-value and a 'customerfriendly' and generic service process (Edvardsson and Modell 1996, p. 16). Customer-friendly services emerge from a dialogue with competent and demanding customers (Edvardsson and Modell 1996), or, as von Hippel (1988) puts it, lead users with extreme demands. Interesting further research here is how open business models and open innovation methods (e.g. Chesbrough and Appleyard 2007, Chesbrough and Schwartz 2007) can be applied to refine methods for the development of PSS in collaborative settings.

\subsection{The voice of the customer in product-development activities}

Both in the IPD and the service development literature, the 'voice of the customer' is central in development activities. As a key to successful product development, the customer view of the product is all encompassing and unconstrained (Mello 2002). Customers perceive products in totality, through the entire product life cycle, ... from initial contact to order entry and through after-sales service and disposal (Mello 2002, p. 66). Therefore, it falls naturally that the manufacturing firm in all product development activities takes life cycle consideration for the product, since a life cycle commitment (contract of the functionality) will be provided to a customer - in the form that is perceived by the customer as more of a service, i.e. activities (Grönroos 2000), than a physical thing. The extension of business models towards life cycle commitments hence calls for the early understanding of services as co-produced with customer involvement, and customer needs (or user in the case where the customer is not the user). Suggesting that the designers of life cycle commitments should interact with customers, or end users, and experience the end-user environment for their projected offering, there might still be a marketing department that make surveys, and an after-sales support section that collects customer feedback, summarising this in customer needs. Those who find the important market or design opportunities and those who are going to solve them are not necessarily the same (Patnaik and Becker 1999, Ulrich and Eppinger 2007). The fact that design work starts as an imprecise task, or fuzzy front end (Smith and Reinertsen 1991), where little of the desired product (function) solution is known makes this a wicked problem (Rittel and Webber 1973). Hence,

\footnotetext{
...before designers can solve a design problem they need to understand some basics - such as what they are designing, what it should do and who should use it, and under what circumstances. (Randall et al. 2007)
}

A product-development process is intended to transform (Krishnan and Ulrich 2001) or translate (Baxter 1995) a market opportunity to a physical artefact. To do that, the designer is recommended to be fanatically customer-oriented and comfortable in marketing, design and engineering disciplines (Baxter 1995). Hence, how to manage a market research or how to gather information on customer are covered in the product-development literature. 
Ulrich and Eppinger (2007, pp. 56-58) present a five-step process to identify customer needs:

- Gather raw data from customers - suggestions are, for example, interviews in focus groups performed in the customers' environment and watching customers use an existing product or perform a task for which a new product is intended.

- Interpret the raw data in terms of customer needs.

- Organise the needs into a hierarchy of primary, secondary and (if necessary) tertiary needs.

- Establish the relative importance of the needs.

- Reflect on the results and the process. This is done for the development team to ... challenge its results to verify that they are consistent with the knowledge and intuition the team has developed through many hours of interaction with customers (p. 67).

From a view of TQM (Clausing 1994), another way to manage needs are advocated. A matrix diagram, such as The House of Quality, is suggested to plan a successful product. It consists of eight fields, i.e., rooms, in which a number of steps are carried out. The Voice of the Customer is a vital concept to bring in needs, requirements, desires and attributes into room 1. Customer needs are described as typically obtained in qualitative interviews.

Typically, each need is a short phrase. In room 1 it is important to stay close to the customer's own language, not modifying it to achieve closer conformity to corporate standards. (Clausing 1994, p. 111)

However, contextual inquiry is also suggested as an alternative to gather customer's needs:

Customers have been satisfying their needs by using one of the company's existing products or a competitor's product. The team will want to observe them using the product in their normal context. The team seeks data that will help it to support, extend, and transform the customer's activities. In order to achieve these goals, it focuses on what customers actually do, rather than on what the say they want. Ultimately the team wants to transform the customer's activity by making it more useful or attractive. (Clausing 1994, p. 116)

\section{Engineering design for functional products}

\subsection{Some PSS reflections on 'traditional' product development}

As discussed in the previous chapter, 'traditional' product development follows the route of interpreting and translating the customer needs into design. This is something that market departments typically are 'in charge' of using customer support functions and sales and support staff to gather data on requirements of the customer or the customer to be. Then, product development personnel at $R \& D$ departments find solutions for the requirements, and services are added on top of the product by a service organisation. The product combined with the added services are provided as an offering and sold to the customer. This realisation can be seen as the phases of the productdevelopment process in Figure 3. Since the traditional product was usually engineered, this process is often referred to as engineering design. Engineering design is the part of product development that involves technically defining the product characteristics, e.g. geometry, components and material, to fulfil the product requirements, e.g. performance, safety, quality, ergonomics, manufacturing, environment, maintenance and cost.

Needs are in this case usually interpreted into requirements on the product to come as being expressed in relation to the foreseen product solution, where the focus is put on what artefact to develop since 'a jet-engine manufacturer manufactures jet engines', but in a PSS view this is likely to change.

PSS implies that the 'classical' product is only a part of the actual solution, as both the ISO definition and the service management literature suggests. In PSS, the product 'properties' may actually be the form of provision to the customer and the services used by the customer, and not only 


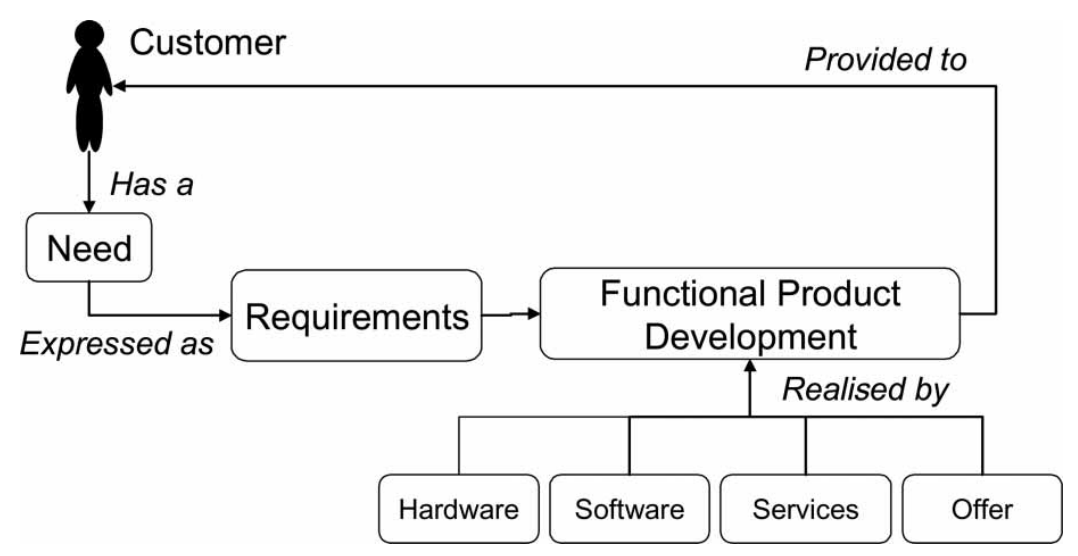

Figure 5. Functional product development.

technical performance metrics. Hence, there is a different viewpoint on what is to be developed. The 'classical' product-development process has the objective of developing the artefact that fulfils the requirement list. The FPD process has the objective of developing the solution (i.e. any combination of hardware, software, services, etc.) to customer needs that create value for the customer (Figure 5).

In the FPD process, the customer needs to play a more integral role in the development. Understanding the needs cannot per se be interpreted as extracting as requirements merely to develop the physical product, mainly since the physical artefact is not solely the final product. Hence, also needs are transformed and expressed in the requirements. The solution to the user need is the PSS which can be embodied by a 'classical' hardware product but equally possible be a pure service. In addition, the offering to the customer is seen as an integral part of the PSS. Finally, a PSS is 'provided' to the customer rather than sold, since the form of customer usage, contract, and payment can be quite different depending on the way the PSS is provided to the customer.

The FPD focuses more onto the customer need phase (Figure 5) of the development process. Ericson (2007) states that

\footnotetext{
... a need-based approach supports innovative and new products and traditional product development seems to support improvement of existing products. Yet both are important to develop functional products. The challenge of integrating the two stances is identified as related to cultural and historical formative issues. Designers are well acquainted with product improvement from a technical point of view, but needs identification is likely to require a non-trivial shift in perspective and in particular will rely on a broadly sociological ability - the ability to observe human beings. Ericson (2007, p. vii)
}

If we define Engineering Design as the engineering work to transform Requirements to Solutions, we have on a coarse level a traditional definition of engineering design work. Following this definition, the engineering design of PSS has a wider spectrum of what design parameters are available. Not only are the hardware properties and software system properties available, but also the 'properties' of services and the actual offering to the customer. This calls for a frontloaded process where customer interactions (needs) come together with the manufacturing firm's in-house skills in order to develop concepts of the solution to come.

\subsection{Customer needs}

The focus on early phases and needs brings the manufacturing firm closer to the customer. Kaulio (1998, p. 143) presents three dimensions of customer interaction in design work: 
- Design for customers - products are designed on behalf of the customer. Knowledge base for the design is data on users, general theories and models of customer behaviour.

- Design with customers - focus on customer preferences, needs and requirements in a 'design for' approach, but different solutions/concepts are displayed for the customer to react on proposed design.

- Design by customers - customers are actively involved and partake in the design of their own products.

Obviously, the focus on the customer is apparent in the IPD line of research, but we suggest that even deeper customer involvement is required for PSS, and therefore look into the service management and service development research field.

However, the placing of the customer in the centre and to regard services from the customer point of view does not mean that the service provider is governed in all respects by the customer. The aim in service development is to create prerequisites for long-term, profitable customer relations, and to attract and keep customers who are satisfied and loyal. Accordingly, in service management, there is a strong focus on customers, i.e. the person or organisation receiving the outcome (Edvardsson and Modell 1996). From a service perspective, business relationships are about

... what firms can do for customers in the form of a total service offering, rather than what it can do to customers with existing products... (Edvardsson and Modell 1996, p. 6)

To find out what to do for customers, information about customers and communication with customers are vital.

The design by customers is in line with the idea of lead-users (Thomke 2001, von Hippel 2005), where providing customers with tools to design and develop their own products is one approach. The lead-user concept is occurring in product-development literature as a way to involve customers to more efficiently, by interviewing, identify needs (Ulrich and Eppinger 2007). However, also approaches that put forward the use of methods that originates from the social sciences are used to interact with customers, or rather users. Broadly viewed, customer-centric product development (Mello 2002) might be categorised into the 'design with customer' dimension, due to its participative approach. Needfinding (Patnaik and Becker 1999), an approach to make the identification of people's needs and design a seamless activity, seems to be difficult to categorise into one of these dimensions. Taking a holistic approach to interact with people, users and customers, it seem like needfinding activities can cut across all the suggested dimensions, and the needs are what enters the FPD process in Figure 5.

A Needfinding approach has been implemented in a small number of cases, whereas IDEO, a leading design firm in the US (Kelley 2001) is one example. In their view, the base in their process is a well-developed and continuously refined methodology, ... it's just that we interpret that methodology very differently according to the nature of the task at hand (p. 6).

This differs from traditional product-development-process models, where an important aspect is to contribute to long-term stability and providing a clear structure, as well as decrease subjective user-information as early as possible.

\subsection{Modelling and simulation}

Modelling and simulation has reached a certain level of maturity for traditional products. It is possible to simulate virtually everything that relates to traditional products, and their features (Figure 6) in terms of performance (material, stress, etc.). Challenges are now more on validating the methods used for virtual verification, realising multidisciplinary simulation, etc., also taking into account the complete product life cycle including, e.g. disassembly and remanufacturing (Östlin et al. 2008). 


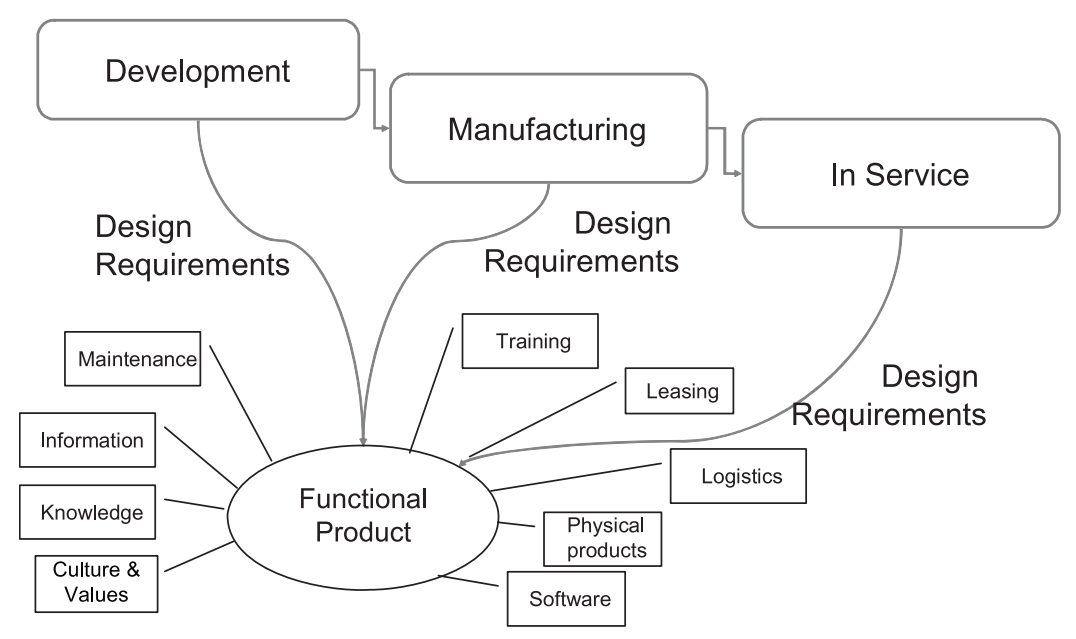

Figure 6. Representing properties of the functional product.

Recently, interest has increased when it comes to modelling and simulating other disciplines, functions and processes, related to the system where products are engineered. In the case of providing functions, this means the modelling and simulation of the integrated design and development of hardware, software and services (additional components needed not excluded). Even modelling and simulation of the offering itself becomes an integral part of the design work of functional products.

Once representing the functional product as a model, it can be designed, defined, modelled, simulated and evaluated. It is possible to 'engineer' the functional product, and an interesting method for increased customer involvement during the complete development process is suggested by Campbell et al. (2007). The challenge is how to represent the properties of services since we may no longer mean dimensions and tolerances of physical artefacts. A systematic approach that incorporates customer operations, based on quality management, is suggested by Schmitt and Hatfield (2008), much in line with Grönroos (2000) and Fransson (2004), pointing out how the provider can take advantage of learning from customer use by for example making invisible services visible. Tools for PSS can be based on combinations of product models and service model, such as the product-service hybrid pyramid presented in Fritz et al. (2007).

\section{New competence requirements for manufacturing firms}

\subsection{PSS requires new competences}

The manufacturing firms studied have to some extent made a business transition from traditional product selling to offering PSS based on the function of the product (see Table 1). Most of them are simultaneously offering traditional products and PSS. In most cases, the studied manufacturing firm works together with customers and partners to fulfil the PSS. Traditional product-development competences required are, e.g. hardware design (including integrated electronics and software), design for manufacturing (DFM) and assembly (DFA), supplier involvement - both component suppliers and sub-system suppliers, and customer requirements on product use (mainly via marketing function), that usually require an IPD organisation. Their traditional product offering are also complemented with additional services such as installation, user training, and after-sales support with maintenance services and sales of spare parts. 
Table 1. From traditional product to PSS for some manufacturing firms, examples of complementary competence required for FPD.

\begin{tabular}{|c|c|c|c|}
\hline Company & $\begin{array}{c}\text { From traditional } \\
\text { product }\end{array}$ & $\begin{array}{l}\text { To PSS (functional } \\
\text { product), example }\end{array}$ & $\begin{array}{l}\text { Example of complementary } \\
\text { FPD competence required }\end{array}$ \\
\hline $\begin{array}{l}\text { Toyota Material } \\
\text { Handling Group }\end{array}$ & Forklift trucks & $\begin{array}{l}\text { Warehouse transportation } \\
\text { solution }\end{array}$ & $\begin{array}{l}\text { Customer's internal logistics; } \\
\text { remanufacturing }\end{array}$ \\
\hline Volvo Aero & Jet engines & $\begin{array}{l}\text { Providing thrust on the } \\
\text { wing 'power by the } \\
\text { hour' }\end{array}$ & $\begin{array}{l}\text { Flight operations; airline customer's } \\
\text { strategy, e.g. environmental } \\
\text { policies }\end{array}$ \\
\hline Marine Jet Power & Water jets & $\begin{array}{l}\text { Water jet propulsion } \\
\text { systems }\end{array}$ & $\begin{array}{l}\text { Customers' jet-boat operations (e.g. } \\
\text { coast guard, yachts, tourist boats), } \\
\text { increased speed (efficiency) with } \\
\text { reduced oil and fuel consumption } \\
\text { (with electronics, control unit, } \\
\text { engine suppliers) }\end{array}$ \\
\hline Sandvik Coromant & $\begin{array}{l}\text { Tools for metal } \\
\text { working }\end{array}$ & Smart manufacturing & $\begin{array}{l}\text { Customer machine investments; } \\
\text { customer value analysis }\end{array}$ \\
\hline ITT Flygt & Pumps & Cleaning solutions & $\begin{array}{l}\text { Functionality of customer plants } \\
\text { concerning wastewater }\end{array}$ \\
\hline Rodeco & Plastic figures & $\begin{array}{l}\text { Adventure pool parks; } \\
\text { playgrounds }\end{array}$ & $\begin{array}{l}\text { Delivery, assembly and functional } \\
\text { testing; playground competence; } \\
\text { children's safety standards; } \\
\text { facilities management (esp. for } \\
\text { tourist parks) }\end{array}$ \\
\hline Svenska Expander & $\begin{array}{l}\text { Spare parts for } \\
\text { machines with } \\
\text { pivots }\end{array}$ & $\begin{array}{l}\text { Expander System } \\
\text { TM (elimination of } \\
\text { mechanical pivot wear) }\end{array}$ & $\begin{array}{l}\text { Customer (forest, digging, etc.) } \\
\text { productivity, i.e. reduced down- } \\
\text { time due to pivot wear; e-business } \\
\text { system for mass customisation } \\
\text { over the internet; fast delivery; } \\
\text { CAD system integration }\end{array}$ \\
\hline Polyamp & $\begin{array}{l}\text { DC/DC converters; } \\
\text { AC/DC power } \\
\text { supply }\end{array}$ & $\begin{array}{l}\text { Naval systems for } \\
\text { mine countermeasure } \\
\text { applications, e.g. } \\
\text { degaussing systems, } \\
\text { magnetic sweep } \\
\text { supply systems, } \\
\text { underwater electric } \\
\text { field measurement }\end{array}$ & $\begin{array}{l}\text { Customer training; reduced } \\
\text { ownership cost; naval industry use } \\
\text { software package for customer use } \\
\text { (co-development with customer) }\end{array}$ \\
\hline Assalub & $\begin{array}{l}\text { Lubrication } \\
\text { equipment } \\
\text { components }\end{array}$ & Lubrication systems & $\begin{array}{l}\text { Knowledge about customer } \\
\text { machinery lubrication need for } \\
\text { reduced lubrication consumption }\end{array}$ \\
\hline $\begin{array}{l}\text { Storebro } \\
\text { Maskinrenovering }\end{array}$ & $\begin{array}{l}\text { Contract } \\
\text { manufacturer }\end{array}$ & $\begin{array}{l}\text { Machine reconditioning } \\
\text { and preventive } \\
\text { maintenance }\end{array}$ & $\begin{array}{l}\text { Systematic de-assembly and } \\
\text { reassembly; problem-solving, such } \\
\text { as replacing old spare parts; no } \\
\text { longer available on the market; } \\
\text { collaboration with programming } \\
\text { firms for computerised control } \\
\text { systems; operator training, service } \\
\text { agreements }\end{array}$ \\
\hline Ocean Modules & Underwater robots & $\begin{array}{l}\text { Underwater operations } \\
\text { such as investigations, } \\
\text { measurements }\end{array}$ & $\begin{array}{l}\text { Customers' (e.g. power plants, oil } \\
\text { platforms) underwater (especially } \\
\text { deep sea) operations (e.g. } \\
\text { constructions, installations and } \\
\text { environmental investigations) }\end{array}$ \\
\hline Industrihydraulik & $\begin{array}{l}\text { Contract } \\
\text { manufacturer }\end{array}$ & Hydraulic systems & $\begin{array}{l}\text { Hydraulic systems for customer } \\
\text { activities, e.g. pulp and paper mills, } \\
\text { water plants }\end{array}$ \\
\hline
\end{tabular}


Furthermore, Table 1 shows examples of how this transition to PSS requires complementary competencies for the manufacturing firm, and especially for its product-development work. It should be pointed out that it is not aimed to be a complete list, since the variations for each firm are too large and depending on each customer and each business case for the firm in question. Nevertheless, all the examples show that IPD is not enough. In most cases, business networks are a prerequisite to fulfil the PSS offering to the customer. Such a business network, with suppliers, partners, and in many cases the customer, also tend to vary from one PSS offering to another. Take MJP's waterjet solution as an example. One customer's application requires collaboration with one control-unit supplier, while a solution for another requires another control-unit supplier. To participate in one or a few long-term stable business networks with the same partners might be a good, but not sufficient, managerial solution. Instead the firms need to manage a multitude of simultaneous business relationships, maybe with competing suppliers and partners. The studied companies seem to need dynamic but at the same time reliable business network relationships for realising their PSS offerings.

Several of the studied manufacturing firms are small, having fewer than 50 employees. Small firms are usually highly specialised, but also in need of several business partners. The focus on core business in the past decades however, has led to specialised companies regardless of size, i.e. this is a conclusion for larger firms as well. Even ITT, which is a large and diversified company group, needs external partners. This also lays the foundation for larger customer participation. Internet communication solutions open to partners make customer involvement even easier.

\subsection{Towards a new engineering environment for FPD}

If we accept that the users need and the market expects products with increasing service content, does this impact the daily work for product designers? What is the impact for the development engineer?

Let us take a simple example of an engineering design situation that may at first glance appear to be a classical mechanical design situation - far from the service provision principles. First some context:

The mechanical engineer's toolbox is typically a CAD tool and some equivalent CAE tools. The example used is a flange design example (Figure 7), which was reported first by Boart et al. (2005). Traditionally, flange design is done using dimensional methods based on mechanistic information such as loads and moments, geometrical boundaries, mechanical properties of the material use and the friction properties and models used to dimension the flanges. Calculations are made either by hand or by more analytical, often Finite-Element-based, tools, and the geometry is eventually defined using a mechanical CAD system.

When introducing life cycle properties following a PSS context, it becomes necessary to define also the properties governing the behaviour during the life cycle of the product. Properties steaming from 'down stream' processes such as manufacturing and maintenance become necessary to model, define and simulate to understand how the functional product will fulfil the needs. If the product will be provided as a PSS where the provider (manufacturer) offers for example maintenance service, the maintenance procedures are known and controlled in advance and integrated. Repair or replace decisions can impact the design decision as well as requirements for maintenance optimisation.

In the flange design example, properties from manufacturing and maintenance were identified, such as manufacturing operations needed to achieve the tolerances required and lead times for assembly and disassembly of the flange mount in the maintenance phases. Rules and dependencies between these properties were directly associated to the CAD model and the flange design now represented not only geometry and materials, but also the required manufacturing operations 

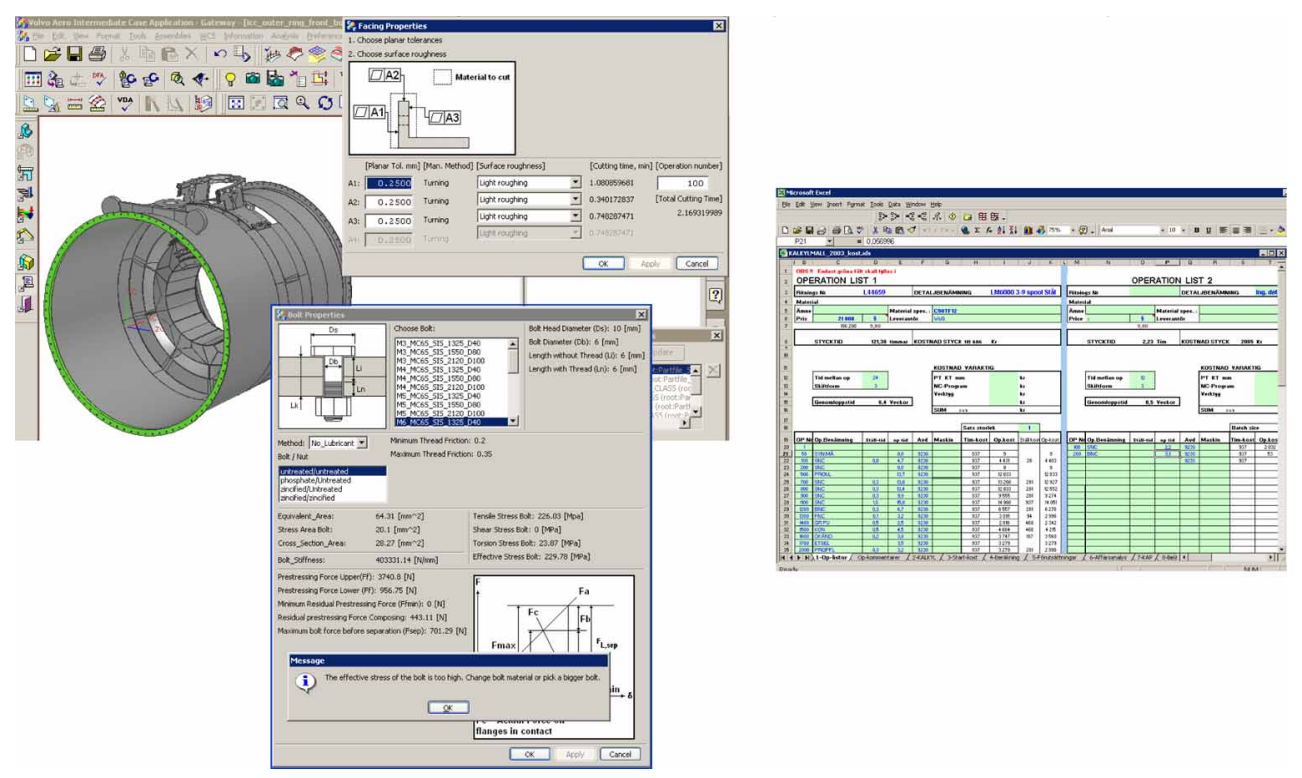

Figure 7. Screenshots of service integration in the engineering-design environment (Boart et al. 2005).

needed, as well as the maintenance conditions for assembly and disassembly. Since the properties were directly associated to the design model, these 'new' properties could be made available instantly as a consequence of a detailed design modification, such as the number of bolts and expected tolerances of surfaces.

The designer who has previously mainly focused on the geometrical design is now directly involved in generating the manufacturing process planning and the maintenance instructions. The model used in design can represent more life cycle properties and the 'designer' of these life cycle properties should consequently be a combination of the mechanical designer, the manufacturing engineer and a maintenance engineer.

If we accept the integrated modelling approach to FPD, the consequence is that the model of the functional product will contain 'properties' that exceed the traditional properties that engineers deal with in product design. A designer of a functional-product model must be capable of dealing with all the competences required from interacting with the customer to understand the needs to find solutions beyond the properties of a traditional product. The solutions to user needs may be found in completely other dimensions than 'merely' new physical-product properties and behaviour. The question is whether such designer exists today. In smaller companies, this may be a fact already, whereas in larger organisations, the width of the task is much too wide for a single person to cover in sufficient depth.

\subsection{Challenges and opportunities}

Similar to the previous research on IPD, the challenges for the manufacturing firm offering PSS lie to a large extent in the early and final phases of the development process (in line with Campbell et al. 2007). Many aspects need to be taken into account as the new product is being conceived, and early design decision determine to a large extent the resulting product, and changes later tend to be more costly. In the case of PSS, successful FPD requires more competencies involved than previously since the scope of the product is larger, and, as the empirical examples of Table 1 shows, to a large extent requires knowledge about the customer's business process. With 
functional products, development methodologies make a transition: moving from IPD, including functions such as manufacturing, R\&D and marketing (Andreasen and Hein 1987, see Figure 4), collaborative product development involving the customer, partners, strategic procurement and supplier relationships (Hamel et al. 1989, Bruce et al. 1995, Lambert and Cooper 2000, von Hippel 2005), to complex, flexible PSS combinations depending on the need of different customers varying for different customers, and for the same customer over time. For the PSS area, McAloone (2008) suggests that research from the (1) innovation, (2) eco-design, and (3) supply-chain fields gives important contributions, in order to encompass sustainability-oriented, product-oriented, actor- and service-oriented perspectives. This implies that the scope for PSS research is definitely wide, and demands research from many fields.

Another aspect that the empirical results reveal is that customer focus and a large number of perspectives taken into account can not only be cared for in the early development phases, but throughout the complete development process. Moreover, PSS contracts including long-term responsibility from the provider side entail high levels of uncertainty. Although as much as possible of this uncertainty should be sought to reduce, the manufacturing firm needs to be prepared for life-long development issues, instead of regarding the product-development process as finished at the launch of the product (compare Figure 3). Nevertheless, speed in the development process is still considered necessary in order to reduce uncertainties in market demand, and to gain market opportunities such as market window and selling before competitors (as illustrated by Wheelwright and Clark 1992). Customer needs (in Figure 5) in the FPD process may change fast, for parts or for the totality of a PSS offering, and require a new development. Despite this larger risk-taking and uncertainty, the manufacturing firm must not release rigidity and quality-assurance methods. Here, already existing methods and tools that enhance quality and flexibility (Clausing 1994, Gerwin and Barrowman 2002) can be further refined for FPD.

Involving customers, and especially lead users, is both a challenge and an enormous opportunity (von Hippel 1988, 2005, Campbell et al. 2007). Observations in the studied firms indicate that few manufacturing firms have really managed to do this. Instead, a waterfall development model is still in use (quite similar to Wright 1998), with a strong focus on systematic control, quality measures and traceability. True flexibility to customer involvement is mainly observed at small and mediumsized manufacturing companies, which also see themselves as competing with high flexibility as a factor for customers' choosing them, sometimes instead of larger firms. The disadvantages of this flexibility are, as one could expect, quality failures and misunderstandings between customer expectations and promises, sometimes at a large cost for the provider. The search for the best tradeoff between the development speed and expenses and product cost and performance presented by, e.g. Smith and Reinertsen (1991), is still at the agenda of FPD, but the difference is that the manufacturer needs to involve the customer and other parties in making these decisions.

Another challenge is the call for true collaboration between service developers and traditional product developers needed internally in large manufacturing organisations. In smaller firms, this may also be called for, but is addressed more naturally since the different tasks in the small firm are carried out by a few persons, with fewer barriers between them. In the small firms, we observed that the service personnel had open communication to the quality and development engineers who were quite aware of, e.g. unexpected field-use of the product. In the large firm, different departments represent different functions causing an, for FPD, unhealthy rigidity with risk of 'throw-over-the-wall' behaviour (Dussauge et al. 1987). Often, services are being developed by organisations apart from the product-developing organisation. A PSS approach requests that the design team develops the artefact and the service simultaneously, in tight collaboration with the customer to capture needs, and with other required partners and suppliers depending on the competencies needed. Work methods for FPD need to go further than previously suggested need analysis such as that by Ulrich and Eppinger (2007), for example as Campbell et al. (2007) suggest. Customer involvement is needed along the process, as is the input from service technicians, and 
other personnel knowing about the customer's changing demand. The ultimate goal would be to anticipate future needs (as suggested Schmitt and Hatfield 2008), something that indeed requires an open-minded organisation (Vargo and Lusch 2008).

The challenge is to implement a robust method for FPD, enabling the manufacturing firm to address varying customer needs, and to involve customers, suppliers, and partners in the development phase, which in turn allows flexibility over time and risk assessment. This is even more accentuated of the fact that in reality, most manufacturing firms need to have a capability to provide both PSS and traditional products due to various demands from different customers. Some customers may wish to purchase the function only, while others want to own their own equipment. For the manufacturing company, a direct consequence of PSS is an increased degree of sophistication in the manufacturing firm's business offerings, affecting the conditions of development of traditional hardware products. Conditions of use of the product are always important input to product development, and becomes even more so in the PSS case. The way manufacturing firms bring forward products is certainly affected, and both the traditional and the PSS situation must be handled.

\section{Conclusions and discussion}

It can be concluded from the findings that manufacturers increasingly offer services integrated with their traditional products. The way these PSS are being developed is less clear. Traditionally, services have been seen as add-ons to the traditional product, and the product-development process has not been affected by the increased service context. The consequence is that services and physical products have largely been developed independently, while PSS are provided as an integrated offering by marketing and sales.

Theoretically we have found it fruitful to combine engineering fields (IPD, quality management) with marketing (services and relationship marketing) in order to deepen our understanding of the FPD process. Models for the traditional product development emphasise collaborative, multidisciplinary work but show weaknesses when it comes to the continuous customer involvement required for service design. Service design, on the other hand, omits the impact on the artefact itself in the service use. In this paper, we argue that a FPD process is needed that accounts for an integrated development of both products and services. The core constituents of the FPD process are as follows:

- Focus on finding solution to customer needs

- High degree of customer involvement during development (which goes further than being customer-centric)

- Networked, global development with customers, partners and suppliers

- Modelling and simulation of all aspects of PSS in early phases

The design engineers are no longer 'merely' designing the physical artefact, but rather a service system wherein the artefact is one constituent. Increased service content in the product calls for a tighter customer integration throughout the development process. Understanding and evaluating impact due to in-service use of the PSS require the entire PSS to be modelled and simulated already in the earliest phases of product development. As a consequence, models, tools and simulation techniques to 'engineer' PSS must represent both properties and behaviour of the artefact for manufacturing, and the governing properties and behaviour of services. Engineering design tools, and product modelling and analysis techniques, now handle process information, business information and service information in addition to the more traditional properties found within the hardware and software design. 
Models for product development need to be enriched with a pronounced customer integration perspective (service driven) while models for service development need to account for dependencies to the artefact.

Notably, the ISO definition of product already covers the integrated product and service concept, while few theoretical models for its development do. Competencies required in development work are also affected. The shift towards PSS development organisations has an impact on the competencies in the FPD process. Service designers need to be involved in the development of the artefact, and traditional product developers need to be involved in the service design. Engineers need to understand, model and simulate value contribution of products and services. Development teams need to tightly integrate not only different functions, but also customers, suppliers, partners, etc.

Increased focus on services along with products also shifts the focus in manufacturing firms from a cost focus to a customer-value focus. Understanding the value contribution of PSS challenges the manufacturing companies and their customers to compose the development team in a new way - focusing on the user needs.

It is likely that innovation is easier to achieve since the design team may be composed radically differently. There are some risks when shifting to an FPD process. An obvious challenge is the collective change in mindset required and the plausible lack of established routines, tools, etc. Another risk coupled to the networked development process is that of intellectual properties. Sharing development work between independent organisations also calls for careful tailoring of intellectual property setup. Cost split in-between risk- and revenue-sharing partners tend to be difficult to master, whereas value contribution may be less controversial. Increased focus on a value-driven development may be a way forward for the networked enterprise, and consequently for the engineering methods and processes as well.

In the networked enterprise, the distributed development work is a fact and how to realise the distributed collaborative work environment is yet another challenge that necessitates a multidisciplinary research approach.

\section{Acknowledgements}

The authors thank all participating companies for their support. This research was mainly financed by the Swedish Governmental Agency for Innovation Systems (VINNOVA) and the Swedish Foundation for Strategic Research (SSF).

\section{References}

Alonso-Rasgado, T., Thompson, G., and Elfström, B.-O., 2004. The design of functional (total care) products. Journal of Engineering Design, 15 (6), 515-540.

Andreasen, M.M. and Hein, L., 1987. Integrated product development. Berlin, New York: Springer-Verlag.

Baxter, M.R., 1995. Product design-practical methods for the systematic development of new products. London: Chapman $\&$ Hall.

Biemans, W.G., 1995. Product development within networks: on the other side of the coin. In: H. Håkansson and I. Snehota, eds. Developing relationships in business networks. London: Routledge.

Boart, P., et al., 2005. A multidisciplinary design tool with downstream processes embedded for conceptual design and evaluation. Proceedings of international conference on engineering design, ICED’05, 15-18 August 2005, Melbourne.

Brännström, O., 2003. Market offer concept development - using a post industrial product construct in practice, EIASM 10th international product development management conference, 10-11 June 2003, Brussels.

Brännström, O., 2004. Market offer development: industrial experiences in a business-to-business context. Thesis (PhD). Luleå, Sweden: Luleå Technical University Publication, ISSN 1402-1544/ISRN LTU-DT-04/38-SE/NR 2004:38.

Bruce, M., et al., 1995. Success factors for collaborative product development: a study of suppliers of information and communication technology. R\&D Management, 25 (1), 33-44.

Campbell, R.I., et al., 2007. Design evolution through customer interaction with functional prototypes. Journal of Engineering Design, 18 (6), 617-635.

Chesbrough, H. and Appleyard, M., 2007. Open innovation and strategy. California Management Review, 50 (1) 57-76. 
Chesbrough, H. and Schwartz, K., 2007. Innovating business models with co-development partnerships. Research Technology Management, Jan-Feb, 55-59.

Clausing, D., 1994. Total quality development - a step-by-step guide to world-class concurrent engineering. New York: ASME Press.

Dussauge, P., Hart, S., and Ramantosoa, B., 1987. Strategic technology management. Chichester, UK: Wiley.

Edvardsson, B., et al., 2000. The effects of satisfaction and loyalty on profits and growth: products versus services. Total Quality Management, 11 (7), 917-927.

Edvardsson, B. and Modell, S., eds., 1996. Service management. interdisciplinary perspectives. Stockholm: Nerenius \& Santérus Förlag.

Eisenhardt, K.M., 1989. Building theory from case study research. Academy of Management Review, 14 (4), $532-550$.

Ericson, A., 2007. A need-based approach to product development. Thesis (PhD). Luleå University of Technology, No. 2007:68.

Fransson, M., 2004. Verkstadsindustrins tjänstefiering - en explorativ resa i det nya affärslandskapet (in Swedish). Licentiate thesis. CTF, Karlstads Universitet, Sweden, No. 2004:24.

Fritz, C., et al., 2007. Research tasks and potentials in product/service-system development. Proceedings of the international conference on engineering design, ICED'07, 28-21 August 2007, Paris.

Gerwin, D. and Barrowman, N., 2002. An evaluation of research on integrated product development. Management Science, 48 (7), 938-953.

Grönroos, C., 2000. Service management and marketing: a customer relationship management approach. Chichester, UK: Wiley.

Gummesson, E., 2002. Total relationship marketing - marketing management, relationship strategy and CRM approaches for the network economy. 2nd ed. Cornwall, UK: Butterworth Heinemann.

Hamel, G., Doz, Y., and Prahalad, C.K., 1989. Collaborate with your competitors - and win. Harvard Business Review, Jan-Feb, 133-139.

Hartley, J.R., 1992. Concurrent Engineering - Shortening lead times, raising quality and lowering costs. Cambridge, MA: Productivity Press.

International Organization for Standardization. ISO 9001:2000. Available from: http://www.praxiom.com/iso-definitions [Accessed 30 June 2008].

Kaulio, M.A., 1998. Customer, consumer and user involvement in product development: a framework and a review of selected methods. Total Quality Management, 9 (1), 141-149.

Kelley, T., 2001. The art of innovation. Lessons in creativity from IDEO, America's leading design firm. USA: Currency and Doubleday.

Kowalkowski, C., 2008. Service productivity gains through information and communication technology applications: a service marketing approach. International Journal of Knowledge Management Studies, 2 (1), 4-22.

Krishnan, V. and Ulrich, K.T., 2001. Product development decisions: a review of the literature. Management Science, 47 (1), 1-21.

Lambert, D.M. and Cooper, M.C., 2000. Issues in supply chain management. Industrial Marketing Management, 29, $65-83$.

McAloone, T.D., 2008. PSS research activities at DTU. International PSS Design Research workshop, 30-31 May 2008, Tokyo. (http://www.pssdesignresearch.org).

Mello, S., 2002. Customer-centric product definition: the key to great product development. Boston: USA: AMACOM.

Normann, R., 1983. Service management. Malmö, Sweden: Liber.

Normann, R. and Ramírez, R., 1993. From value chain to value constellation: Designing interactive strategy. Harvard Business Review, 71 (4), 65-78.

Normann, R., 2001. Reframing business - when the map changes the landscape. Chichester: John Wiley \& Sons Ltd.

Öhrwall Rönnbäck, A., 2002. Interorganizational IT support for collaborative product development, Thesis (PhD). Linköping University, IMIE no. 59, EKI no. 54.

Oliva, R. and Kallenberg, R., 2003. Managing the transition from products to services. International Journal of Service Industry Management, 14 (2), 160-172.

Östlin, J., Sundin, E., and Björkman, M., 2008. Business drivers for remanufacturing. Proceedings of the 15th CIRP international conference on life cycle engineering, April 2008, Sydney.

Pahl, G. and Beitz, W., 1996. Engineering design. A systematic approach. London: Springer-Verlag.

Patnaik, D. and Becker, R., 1999. Needfinding: the why and how of uncovering people's needs. Design Management Journal, 10 (2), 37-43.

Prasad, B., 1996. Concurrent engineering fundamentals - integrated product and process organization. Vol. 1. Upper Saddle River, NJ: Prentice-Hall.

Pugh, S., 1991. Total design - integrated methods for successful product engineering. Wokingham, UK: Addison-Wesely.

Randall, D., Harper, R., and Rouncefield, M., 2007. Fieldwork for design-theory and practice. London: Springer-Verlag.

Rittel, H. and Webber, M., 1973. Dilemmas in general theory of planning. Policy Sciences, 4, 155-169.

Roozenburg, N.F.M. and Eekels, J., 1995. Product design: fundamentals and methods. Chichester, UK: Wiley.

Senge, P. and Carstedt, G., 2001. Innovating our way to the next industrial revolution. MIT Sloan Management Review, Winter 2001, 24-38.

Schmitt, R. and Hatfield, S., 2008. Strategic servicification - a quality based approach beyond service-engineering. In: M. Mitsuishi, K. Ueda, and F. Kimura, eds. Manufacturing systems and technologies for the new frontier, 41st CIRP Conference on Manufacturing Systems, 26-28 May 2008, Tokyo. London: Springer-Verlag, 511-514.

Smith, P.G. and Reinertsen, D.G., 1991. Developing products in half the time. New York: Van Nostrand Reinhold. 
Thomke, S., 2001. Enlightened experimentation - the new imperative for innovation. Harvard Business Review, February, $66-75$.

Ullman, D.G., 2003. The mechanical design process. 3rd ed. New York: McGraw-Hill.

Ulrich, K.T. and Eppinger, S.D., 2007. Product design and development. New York: McGraw-Hill.

Vandermerwe, S., 2000. How increasing value to customers improves business results. Sloan Management Review, Fall, $27-37$.

Vargo, S.L. and Lusch, R.F., 2004. Evolving to a new dominant logic for marketing. Journal of Marketing, 68, 1-17.

Vargo, S.L. and Lusch, R.F., 2008. From goods to service(s): divergences and convergences of logics. Industrial Marketing Management, 37, 254-259.

von Hippel, E. 1988. The sources of innovation. Oxford University Press.

von Hippel, E. 2005. Democratizing innovation. Cambridge, MA: MIT Press.

Wheelwright, S.C. and Clark, K.B., 1992. Revolutionizing product development: quantum leaps in speed, efficiency, and quality. New York: Free Press.

Womack, J.P., Jones, D.T., and Roos, D., 1990. The machine that changed the world: based on the MIT 5-million-dollar 5-year study on the future of the automobile. New York: Rawson Associates.

Wright, I.C., 1998. Design methods in engineering and product design. London: McGraw-Hill.

Yin, R.K., 1994. Case study research: design and methods. 2nd ed. Thousand Oaks, CA: Sage. 